\title{
AFTER IN DEFENCE OF THE SCHOOL: AN INTERVIEW WITH JAN MASSCHELEIN AND MAARTEN SIMONS
}

\author{
DEPOIS DE EM DEFESA DA ESCOLA: UMA ENTREVISTA COM JAN MASSCHELEIN \\ E MAARTEN SIMONS
}

\author{
DESPUÉS DE DEFENSA DE LA ESCUELA: UNA ENTREVISTA CON JAN \\ MASSCHELEIN E MAARTEN SIMONS
}

Alexandre Filordi de Carvalho'; Julio Groppa Aquino ${ }^{2}$

\begin{abstract}
The intent of the interview with the authors of In defence of the school was debating the reception of such book in the context of educational research in Brazil. On one hand, the very outreach of the idea of defending the school was inquired, taking into account the socio-historical context which still circumscribes the school in the functional register of State apparatus. On the other hand, and as a consequence, once again was called into question the book's theoretical horizon, capable of substantiating the defence of the school as res publica. On both fronts, the interview ends up shedding some light to a triple problematization: a) the impasses as to what arguing in favor of formal education nowadays means; b) the consequences of school practice being thought only according to a theoretical-pedagogical dimension, as the authors maintain; c) the constant tension existing between the actualization of historical experiences in the multiplicity of school context and the presupposition of thinking of a general school model. Stemming from the interview, either the opponents or the proponents of Masschelein and Simons' theses obtain new tools to rethink the ethico-political contours of In defence of the school.
\end{abstract}

KEYWORDS: Jan Masschelein. Maarten Simons. In defence of the school. Interview.

\section{RESUMO}

O intuito da entrevista com os autores de Em defesa da escola foi o de debater a recepção da referida obra no contexto das pesquisas em educação no Brasil. Por um lado, tratou-se de indagar pelo próprio alcance da ideia de defender a escola, levando em consideração um contexto sócio-histórico que ainda circunscreve a escola no registro funcional de aparelho de Estado. Por outro lado, e como consequência, recolocou-se em questão o horizonte teórico do livro, capaz de sustentar a defesa da escola como res publica. Em ambas as frentes, a entrevista acaba por lançar luz a uma tríplice problematização: a) os impasses acerca do que significa argumentar em favor da educação formal na contemporaneidade; b) as consequências de se pensar a prática escolar apenas segundo uma dimensão teórico-pedagógica, como defendem os autores; c) a constante tensão existente entre atualização das experiências históricas na multiplicidade do contexto escolar e a pressuposição de se pensar um modelo geral de escola. A partir da presente entrevista, tanto os críticos quanto os signatários das teses de Masschelein e Simons ganham novas ferramentas para repensar os contornos ético-políticos de Em defesa da escola.

PALAVRAS-CHAVE: Jan Masschelein. Maarten Simons. Em defesa da escola. Entrevista.

\footnotetext{
${ }^{1}$ Doutor em Educação - Universidade Estadual de Campinas (UNICAMP) - Campinas, SP - Brasil. Graduado em Pedagogia - Universidade Estadual de Campinas (UNICAMP) - Campinas, SP - Brasil. Professor em Educação Universidade Federal de São Paulo (UNIFESP) -São Paulo, SP - Brasil. E-mail: afilordi@gmail.com.

${ }^{2}$ Doutorado em Psicologia - Universidade de São Paulo (USP) - São Paulo, SP - Brasil. Graduação em Psicologia Universidade Estadual Paulista Júlio de Mesquita Filho (UNESP). Professor - Universidade de São Paulo (USP) São Paulo, SP - Brasil. E-mail: groppaq@usp.br
}
(C) ETD- Educação Temática Digital
Campinas, SP
v.19
n.4
p. $705-719$
out./dez. 2017 


\section{RESUMEN}

El propósito de la entrevista con los autores de Defensa de la escuela fue debatir la recepción de esta obra en el contexto de las investigaciones sobre educación en Brasil. Por un lado, se trató de indagar el propio alcance de la idea de defender la escuela, teniendo en consideración un contexto socio-histórico que aún circunscribe a la escuela en el registro funcional del aparato de Estado. Por otro lado, y como consecuencia, se volvió a colocar en cuestión el horizonte teórico del libro, capaz de sustentar la defensa de la escuela como res pública. En ambos frentes, la entrevista culmina dando luz a una triple problematización: a) los impasses acerca de lo que significa argumentar a favor de la educación formal en la contemporaneidad; b) las consecuencias de pensar la práctica escolar sólo como una dimensión teórico-pedagógica, como defienden los autores; c) la constante tensión existente entre actualización de las experiencias históricas en la multiplicidad del contexto escolar y la presuposición de pensar un modelo general de escuela. A partir de la presente entrevista, tanto los críticos como quienes suscriben las tesis de Masschelein y Simons, ganan nuevas herramientas para repensar los contornos ético-políticos de Defensa de la escuela.

PALABRAS CLAVE: Jan Masschelein. Maarten Simons. Defensa de la escuela. Entrevista.

[INTERVIEWER] - How do you conceive the broad reception which the book In defence of the school has had in Brazil? Would there be in such a reception a sign of exhaustion of the critique of the school modus operandi towards a potentializing turn of the conventional school activities? Or does the latter point to another political horizon?

[MASSCHELEIN] - Maybe a first thing to say is that - we have to repeat it always again - the idea of the book is not to restore the traditional school, so that is not the point. It is not about going back and it is not a celebration; it is not a kind of romanticism about an old school, which has never existed, and so on. That is really not what we want to do.

We - and Maarten even more than I - have been working for a long time on a kind of critical ontology of education. So, you could say that we have made very critical analyses of what is going on in the field of education, the kind of governing and of subjectivity that are involved. But, here the point is not so much to go into critique, but into what lan Hacking has called a creative ontology: not a critical one, but a creative ontology in order to try to talk in a different way about school, to open up something, not to restore something.

It also has, of course, to do with the fact that we ourselves became more aware of what is also going on in schools, at universities, and of thinking about what makes the school a school, the university a university.

[SIMONS] - I think that is one part. I think indeed that this creative ontology of the present is about introducing new concepts, words, trying to name or refer to specific kind of gestures and experiences, to the specific forms that make a school. Of course, in the book, we gave some examples: sometimes old examples, sometimes new examples.

But I do not think that it was our idea that we make a kind of blueprint for a school to be built. For us, the issue there - and that is what we introduce at the end of the book - is

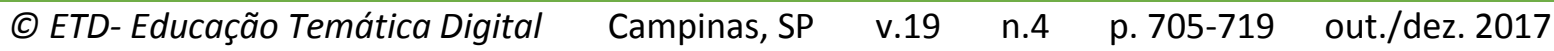


a kind of experimental attitude. I think we can and we should try to invent new practices, new techniques, new modes of organizing space and time in order to make school happen.

And, in a way, that was for us also what we pointed at towards the end of the book when referring to the issue of the curriculum. I think the book offers a way of thinking about a curriculum that is not just a kind of politicized version of how to decide on the curriculum and who should decide on the curriculum. Our point of departure is that if a society accepts school - not just socialization, not just initiation, but school -, meaning that a society also takes the risk that society is not reproduced; if that is the case, we think that the school poses a certain responsibility on society and the first responsibility that the school imposes on society is to discuss and to decide on what should be grammatized.

Just take the example of what is going on in Belgium: we have now a kind of discussion on the core curriculum. Of course, this discussion is very much framed in terms of what society expects from teachers, from schools. We, as a society, expect certain things from the school and the school has to be organized in such a way that it can meet these expectations. But what we try to indicate is that, before making that movement in terms of expectations, society should reflect upon its grammar. What are the key issues in a society that need to be grammatized in order for a new generation to be able to relate to society, to prepare themselves for society, and foremost, to offer them the opportunity to renew society.

So, in that sense, it is not that a society should decide on the image of the ideal citizen and expect the school to shape young people according to this image. I do not think that is something society can expect from a school. But what society should decide is what the basic grammar is that should be put on the table in order for the new generation to give shape to itself. In other words: society should not decide on the idea or ideal of the citizen or personhood or the ideal man/woman, but should decide on what is needed in order for a new generation to create themselves or to shape themselves. I think this can reframe a bit the discussion on the curriculum, which is also a very practical discussion..

Is it about the daily life of a school? Yes and no. Yes, it is a very practical thing and it is a very important thing. What we hope - with this creative ontology of the present - is to reframe the way the discussions are going today.

[MASSCHELEIN] - To continue upon this idea of the grammar of the school and maybe it will come up again later on, a good, actual example would be 'Google'. If we start from the school as a place where society offers the grammar - its grammar - so that the new generation can relate to what is happening in society and relate (i.e. take a distance) to what influences their lives, then school is not about learning how to use Google, but about

$\begin{array}{llllll}\text { (C) ETD-Educação Temática Digital } & \text { Campinas, SP } & \text { v.19 } & \text { n.4 } & \text { p. 705-719 } & \text { out./dez. } 2017\end{array}$ 
it's 'grammar' (its algorithms, its operating mode, how it works). Or put differently: today, in the context in which Google is influencing so strongly our lives, a society that decides to have schools (that is a place where the new generations are not just socialized but get the means to shape themselves, and not just are being shaped) should probably force Google to make its 'grammar', its mode of operation, its basic algorithms available, to put them on the table (make them public in that sense). It is a request that follows from the decision to have schools, as this particular way to deal with new generations.

[INTERVIEWER] - It is not to instrumentalize the children to learn to do something.

[INTERVIEWER] - One of the most marked and no less controversial ideas of the book seems to be the re-enchantment with the school rituals, according to a kind of maximal potency of addressing the new generations materialized in a minimal mode of selfconducting, so to speak. Is this what the poor pedagogy is about? If so, to what ethos does it precisely aspire to?

[SIMONS] -The assumption of such a pedagogy or school pedagogy is the assumption or the strong belief that human beings are not born with a destiny or destination: there is no natural destination. If you do not take that as an assumption, it does not make sense to work in a school. So school starts from a really strong belief that we are born without destiny.

The consequence is that we have to find our destiny and school is a very specific place and time where we allow the newcomers to find their destiny. The consequence is also - and that refers to what we were just saying before - that school cannot start from a kind of ideal of what the developed person should be or from an image of the ideal citizen.

The school is not the means towards ends. And that is the idea of a poor pedagogy. In a way, and drawing on Agamben, school is a means without ends. It is a kind of means that we give to the young generation, and where grammar or algorithms play a very specific role, but in order to make a destiny - or a shape, or a form - possible.

[INTERVIEWER] - By themselves.

[SIMONS] - By themselves. That is, in our view, the idea of making school.

[MASSCHELEIN] - This idea of poor pedagogy, indeed, is related to this element of beingwithout, being-blind in a certain way: having no goal, no destination. But the term was also chosen in relation to the means themselves, so that the pedagogical means themselves in some sense always imply a kind of essentialization or elementarization.

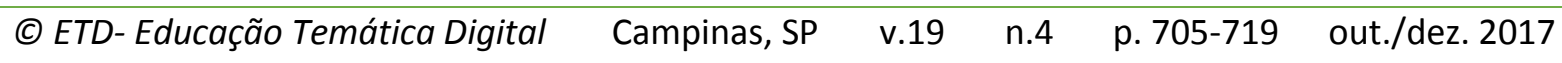


[INTERVIEWER] - And the idea of some ethos is like this: some students will be able to do something for themselves.

[SIMONS] - It is always quickly framed as a kind of student-centered pedagogy or pupilcentered pedagogy where the teacher is avoiding all interventions. I think there is a risk in that.

The way we write it, it is neither student-centered nor a teacher-centered pedagogy, but a kind of subject or grammar-related pedagogy. This is important: the school should not be centered around the individual or the person. I do not think that is the idea of a poor pedagogy, although it is often framed in that way.

To put it another way: if indeed school is about giving the chance to children to leave the family, to leave the family behind or to escape their life-world, someone is needed to help them. That is one thing.

But the other thing is also that there should be something that makes it worth leaving their homes and life-worlds, what we referred to as the world or something of the world that becomes interesting. I think that it is an important issue: something - 'school stuff' - that offers children or pupils the opportunity to give shape or form to themselves. This is only possible when there is something put on the table, only then we offer youngsters the opportunity to really leave their homes or leave their life-world.

This pedagogy is different both from a kind of progressive and conservative pedagogy. Progressive pedagogy is often about "Ok, let's sit around the table, but we are not going to put something on the table; you can put whatever you want; find it out for yourself." I think that is not the idea that we have developed. We should put something on the table and that is what the teacher does. But she leaves it on the table, she sets it free.

Progressive pedagogy is often putting nothing on the table. Conservative pedagogy is putting something on the table, but without setting it free; the teacher keeps it in her own hands.

[MASSCHELEIN] - In a certain sense for them there is no table.

[SIMONS] - There is something, but they hold it in their hands: "This is how you should use it." The pedagogy that we try to describe is: put something on the table and make it free for use - it is a kind of offer that you make. And that makes it of course a poor pedagogy, because you do not hold it as something sacred like in a kind of conservative pedagogy.

[MASSCHELEIN] - And the offer makes only sense if you can make it speak. So it is not just to say "This is a buffet, you can take it," it is also to say "Look, we are putting this on the
(C) ETD-Educação Temática Digital
Campinas, SP
v.19 n.4
p. 705-719 out./dez. 2017

[709] 
table" and "Look, this is very interesting; this is really very interesting," but to say it in a way that you can make it interesting without making it imposing. That is not imposing something, but making it interesting.

Maybe there is another element which could relate to this - because I do not know exactly to what you refer with "the ethos" - and this may be something related to the fact that in the school, today, in a certain discourse about education, you have this language of the production of learning-outcomes. It seems as if education is a kind of production process.

We try to say: no, it is not. We should not think about it as a production process, but as a process which - it is a word which also has some connotations which are maybe not the ones we always want - is taking care. Taking care of the new generation, as Bernard Stiegler argues, but also of something. In that sense, it is also related to a kind of ethos, you could say, of care, which is maybe different from production. This notion of care is multilayered and it could tend to take too quickly an ethical understanding. What we are really trying is to make a point for an educational understanding of the school and not an ethical one. There is a difficulty there.

This is similar to the political. It is not that we think you cannot talk ethically or politically about the school. Of course you can and, of course, there are ethical and political elements that you have to discuss. But let us first try to see if we can talk pedagogically or educationally about the school, taking the school out of the immediately political and ethical - we talk about that in the book: not to go too easily or too quickly to Politics, to Ethics. Which, again, is not to forget about them.

[SIMONS] - Let me refer to that. What we noticed in the reception of the book in Belgium is that often the book is criticized for being naive in the sense that we do as if the school is an island, as if there are no social, cultural or political influences, so that it is a kind of island of freedom and equality.

We are not ignoring, of course not, that there is a social influence. That is evident. What we do in the school, the clothes that people wear, how they speak, that is influenced by things outside. But our point is that adopting a sociological or an economical or a political perspective to understand the school is missing the point. If you look from a cultural point of view or, let's say, sociological point of view you are looking at mechanisms of initiation or socialization. And, of course, there are mechanisms of initiation or socialization and also that is one kind of learning. But we are not interested in initiation or socialization, we are interested in school learning. If you look from an economical perspective, education becomes part of the investment in human capital and individual or social rates of return,

$\begin{array}{llllll}\text { (C) ETD-Educação Temática Digital } & \text { Campinas, SP } & \text { v.19 } & \text { n.4 } & \text { p. 705-719 } & \text { out./dez. } 2017\end{array}$ 
but it is a very specific way of looking at education and learning that in our view misses the whole point about school learning.

Again, we are not ignoring those perspectives, and we are not ignoring the practices related to that, but, perhaps, it is also interesting to look from a pedagogical perspective and not immediately reduce this perspective to applied Sociology, applied Politics, applied Cultural Theory, applied Psychology. The criticism is often that we are naive and ignoring that there are other influences. It is not about that. Perhaps the others are naive in forgetting about the specificity of a pedagogical perspective.

[MASSCHELEIN] - It really is also an attempt to take the school as a kind of place where something can happen, where something has happened and something is happening. If you try to talk about what it is that is happening, then maybe the sociological language, the psychological language, the ethical language are not precise, sufficient enough to say what is happening when we are gathered in this way we call school. And which is not always happening, of course.

[INTERVIEWER] - In one review [GERALDI, João Wanderley. Na figura do professor, o amor do mundo é central. [To the teacher's figure, the love of the world is central] Leitura: Teoria \& Prática, Campinas, v. 32, n. 63, p.169-176, dez. 2014], the eminent professor at UNICAMP addresses the book rather bluntly. What is your position in relation to Geraldi's critique? Here it is:

\footnotetext{
How is one to trust the renewal of society to the teachers, if the very school to be reinvented, the school of the experimental, the school of the free-time, should have as its constitutive elements the school subjects, namely the "school disciplines", which already are themselves saturated with meanings (of modes of understanding the world), dominated by the same spatial forms and by the same time pace marked by school bells?
}

These ambiguities and the unconditional defence of the materiality of a world already signified by school disciplines - as if these presented the world and not a selection of forms of understanding the world - as constitutive to the school which is to be reinvented make this book extremely dangerous, not in the sense that it makes one think, but in the sense that it makes one accommodate, in an apparently new language, all that is old in the school and all that is needed to overcome in order for a renewal to really happen.

Or do the authors consider that reinventing the school is restoring the Enlightened school of the XIXth century?

[MASSCHELEIN] - It is a very, very strange reading. Maybe I am sorry for the reviewer, but that is a very bad reading. In the book, we explicitly deal with this issue of discipline, so if you say "free time" - le temps libre -, it is not just to sit like this and to think what you want. The free time is the free time to study, to exercise.

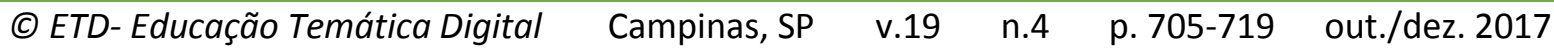


Maybe we should ask the reviewer to explain what it means to exercise without discipline? To perform certain kinds of study without certain discipline? Sorry, but the discipline that we are talking about in the book is discipline which is not discipline in the sense of that it is imposing something from an external source. It is discipline, but it is not required by the State. It is not discipline which is required by the teacher. It is not a discipline required by any institution. The discipline that interests us is the discipline required by the study or to (be able to) study, required by the subject. It is "how can we make study possible?", "how can we make possible that you get into a kind of relation of study?" Then the study is the discipline.

[SIMONS] - Of course, there is this Foucauldian association with "discipline," but I think even in Foucault, even in Surveiller et punir, he makes a difference between disciplinary power and normalization. What he is interested in is how disciplinary power becomes linked up with normalization and in that sense how the modern school becomes a kind of productive social machine. But I think that he is not saying that disciplinary power involves always a kind of normalization. Foucault - in his later work, when he focuses on ascesis - is writing a kind of genealogy of spiritual discipline, going back to Greek Antiquity, where you have a discipline which was not normalizing.

I don't think discipline but the link between discipline and normalisation is a typical feature of XVIIIth and XIXth century society. And no, we don't want to restore that. So, in other words, I can see that discipline and normalization have often been connected, but in schools, even today, they are often also disconnected: study and learning practices that follow rules but without submitting oneself immediately to externally imposed social norms. There is a kind of discipline in schools which is not immediately normalizing. In that sense, I do not know at what that question is exactly aiming. In my view, it is about reinventing certain practices within schools, things which teachers are often doing on a very small scale; and they can invent them in schools because there is no natural, logical connection between this kind of pedagogic discipline - what is asked of students in view of study - and what is required from society.

In that sense, there is a lot of space, time, opportunity to try out, to invent, to reinvent. But this reinvention will not be about how to learn or study without discipline. I do not think this is possible. But again, discipline in a positive sense. If you want to learn or study something, you cannot do everything else at the same time; so, in order to do study or learn, you have to keep other things out. Pedagogic discipline is about that: it is about putting aside, for a moment, other things, in order to be apt to take care of something.

[MASSCHELEIN] - You have no free time without discipline, because discipline, even if it is to keep something out, you already need separation. So it is a very strange reading.
(C) ETD- Educação Temática Digital
Campinas, SP
$\begin{array}{ll}\text { v.19 n.4 } & \text { n }\end{array}$
p. $705-719$
out./dez. 2017 
[SIMONS] - It is fascinating to see that discipline has a kind of positive connotation in sports, for instance. How we all are looking up to the sportsmen, heroes, But they live a very disciplined life. Body-building, exercising. Their discipline means they take care of something, they focus on something and, in order to do that, they cannot do other things. For a moment.

In a way, I think what happens at the school is the same. It is not about discipline in the sense of normalizing, submitting someone to a social norm - that is something different. Disciplining in the sense of making something possible, working on one's condition, and as a result putting aside other things. And I think there are almost no activities which do not require a certain kind of discipline.

It all depends on how one understands and organizes the submitting one's self to something. Submitting oneself to a norm, that was what Foucault was focusing on in Surveiller et Punir. It is very different from submitting oneself to a rule, like a religious rule in the old monasteries. Or the submission to a law, in juridical terms, which is also very specific. We think there is a thing like school discipline and there is something like a school rule. And then we are back to this idea of a poor pedagogy: it is not a rule that leads to a good life in religious terms, it is not a norm in the view of being normal in a social sense; but it is a rule that makes study possible. School rules are about offering someone the opportunity to shape oneself in relation to what is put on the table.

[INTERVIEWER] - Upon the meanings attributed to school acting on In defence of the school, how may one perspectivate the unprecedented expansion of allegedly pedagogical or pedagogizing, to put it better - practices, through numberless social practices? Would it be plausible to state that the more the pedagogical discourse deterritorializes, pulverising itself through social and cultural space, the more it undermines the school interior, disqualifying progressively the array of a teacher's competences? What is it that, after all, a teacher does that no one else could do?

[MASSCHELEIN] - This notion of pedagogization is of course referring to a very particular process and is taking the notion of pedagogy in a certain way from which we want to distance ourselves. Do you need a teacher? It depends on what you want. But maybe you need the school. Or you need a school teacher, maybe. Or better, maybe it is worthwhile to have schools and schoolteachers.

[SIMONS] - I think that is also one of the reasons why we wrote the book: this whole idea that we learn all the time, a life of learning, and that also is a life-wide learning, that we should learn at all places.

$\begin{array}{llllll}\text { (C) ETD-Educação Temática Digital } & \text { Campinas, SP } & \text { v.19 } & \text { n.4 } & \text { p. 705-719 } & \text { out./dez. } 2017\end{array}$ 
We are not criticizing learning. Our point of departure is that we think there is something specific about school learning. And of course you can learn on the job; you learn in the family, from your parents, with your parents; you can learn in the streets. Of course you learn all the time, everywhere. You have different forms of learning: cultivation, masterapprenticeship relation, socialization, or initiation. Different types of learning.

For us, it is about what is specific about school learning. And, if there is something specific, is it worth defending the latter. In the book, we just try to say "yes, there is something specific about school learning." It is a kind of collective learning. It is about making renewal possible. It is the only type of learning that starts with the assumption that human beings do not have a destination. In initiation the end is defined in advance; in socialization you make the same assumption. Also in so-called forms of "natural learning," in which learning is a kind of natural development, you also assume that the outcome or direction is predetermined. School learning starts from the radical assumption that there is no given destination, and thus, school learning is about giving young people the opportunity to give shape to their lives.

But then the question of the teacher. I think, somehow, a school teacher is needed, because typical for school learning is this double gesture: it is done out of love for the coming generation and out of love for the world. The school teacher can be one, or two, or a team - the typical figure of the school teacher can be organized in a different way -, but there should be a kind of moment when something or someone is putting something on the table and asking for attention to what is put on the table. So the school teacher is the figure that can have different shapes, but it is a figure who embodies that double gesture.

[INTERVIEWER] - There seems to be on the book In defence of the school an Arendtian underpinning to the reflections on school temporality, mainly as far as that kind of love for the world, of unconditional attention to the public sphere, of common life, amongst other notions, are concerned. And as far as the Foucauldian thought on In defence of the school is concerned, what is its place?

[SIMONS] - There is of course this association - "il faut défendre la société," "il faut défendre l'école." In that sense, "il faut défendre l'école" could be a kind of expression of someone at the end of the XIXth century who was saying "We need school in order to socialize the future generation." But what we prefer is "il faut défendre l'école" as more similar to "il faut défendre la démocratie," which is different.

You could say the school is a weak educational system. Democracy is a very weak political system. Democracy starts from the assumption that there is no natural or pre-given

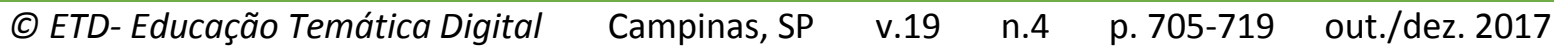


arkhé. There is no natural ground for authority or power. In principle, everyone's voice counts as equal.

There is always a risk involved in that. There is a scandal, as Rancière explained very beautifully: every voice counts, there is no prior qualification or expertise needed to have power. This is a major risk for all elites that claim privileges. In a way, there is a risk involved in school as well. School starts from the assumption there is no destination, no natural relation to future or that it is not given by 'nature' what we will become. The consequence is that school can question all social privileges or any so-called natural order or hierarchy, and therefore the attempts of the elites to neutralize school, similar to neutralizing democracy. We want to defend the school like we also want to defend democracy.

[MASSCHELEIN] - Continuing in the same line, maybe you could say that probably if you want to manage social life, democracy is not the most efficient or effective way to do so. To manage learning, to make it efficient and effective, probably you do not need school. It is not the most effective and efficient way, but maybe it is something that you have to defend because it does more justice to things. You are not to defend democracy for the fact to be efficient and effective. No, it is very often a non-efficient, non-effective system.

[SIMONS] - It is very expensive, and other forms of learning are perhaps much cheaper.

[MASSCHELEIN] - But it does more justice, maybe, to freedom, to justice itself. So, in that sense, school is something that has to be defended. We think it has to be defended essentially in a way related to this idea, this assumption - which is maybe also the basic belief of educationalists - that there is really nowhere written where we have to end up. Human beings have to find their own ways.

That is a very strong assumption, but that is something which is probably essential for education. Can you have education without this assumption? Can you have democracy without the assumption of equality?

[INTERVIEWER] - Given that school education is, after all, one of the most intensive practices concerning the games of conducting of oneself and of others, one could imagine, somehow, that there are traces of Foucault's later thought on In defence of the school. Having in mind the possible confrontation of veridiction/subjectivization processes available to the present, would there be an (ancient) philosophical call to (contemporary) pedagogical discourse, whatever the latter may teach, wherever it may happen?

[SIMONS] -There is an inspiration there. For instance, if we are trying to speak in a positive way of discipline or pedagogic discipline, the reading relates to Foucault and The Hermeneutics of the Subject, in which he tries to retrace the different technologies of the

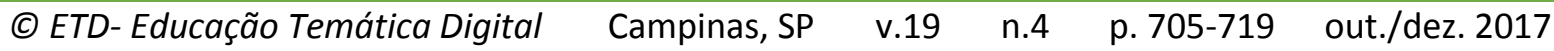


self to a kind of disciplining or ascèsis. He uses different concepts, but we are really very much inspired by that: that you can shape yourself, and foremost that certain technologies are needed in order to give shape to yourself.

It is also fascinating to see that the later Foucault had a kind of sympathy with his object of study. With the prison and earlier with the clinic, there was always a kind of aversion of these institutions, a kind of critical relation. I think that, at the end of his work, he was looking for practices with which he had a kind of affinity. Of course he was also criticizing certain tendencies and developments, but at the same time he had a kind of sympathy with those technologies of the self. So you could say he was also moving towards a, to use Hacking's terms again, creative ontology of the present: trying to think the present, not just by trying to criticize the present, but by trying to open up, in the present, a positive way, a kind of space to relate in another way to our present. Also at that level there is a kind of inspiration for our book.

INTERVIEWER - Concerning the notion of skholé (free time) present In Defence of the school, its relation with the Epicureanism was not considered. But we know that skholé, at least in Epicureanism or Stoicims points to a private experience. Therefore, skholé was used in the book for a public perspective. Is not there a kind of anachronism in the use of the notion of skholé?

[MASSCHELEIN] - Maybe we should also try to say that we do not claim to make a kind of historical analysis of how the school started, etc.

You could say that the invention of the school is precisely to offer skhole to everyone, and we should add, in principle. But offering skholé to everyone is not a decree now saying: "We are going to offer you free time: now you have free time." This free time is created by a kind of materialization and spatialization, in a certain way. So it is to bring people and things together in a certain way.

The skhole is not something that is there and you can have it or not have it, but it is something that is created or can emerge. School is the creation, through bringing people and things together in a certain way, which makes that this free time, in the sense we use it as time of attention and study, happens, is produced to some extent. It is related - Maarten already referred to it - to the collective. It is a collective issue. It is related to very concrete practices that are dealt with.

We should also stress that this creation of the skhole is being related to the invention of alphabetic writing. This alphabetic writing is in itself an element of making knowledge, for example, public and available. What happened by the invention of school was that all kinds of arrangements and also technological inventions, in a certain way, come

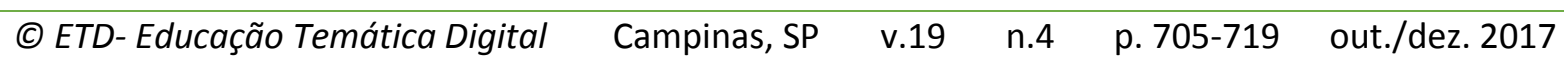


together and created a particular effect. We try to use the notion of school not as a kind of abstract idea or condition or something like that.

INTERVIEWER - Nowadays there is a growth of deschooled education movements. In such sense, anarchists also pointed some directions, for example, the Society Deschooling work of Ivan Illich. Why this questioning was not taken into consideration in In defence of the school?

[SIMONS] - You have the whole deschooling movement in the US, which sometimes refers to Illich but there is a big difference: it is quite a conservative movement, trying to keep the children at home far away from the evil world, so to speak. That is a kind of deschooling that defends an assumed natural learning in the family. For us, school learning starts when you have the time and place to leave the family, and all expectations related to that, to prepare for something else.

In relation to Illich and deschooling or the Deschooling Society book, I think even in Illich there is a kind of ambivalence there. He seems to assume a kind of natural learning, the school is a kind of institutionalization of learning and we have to go back. For him, school and schooling in the process of institutionalization are synonyms. For us, they are not synonyms. We are defending the school but not a kind of institutionalized or tamed version of the school. There is a big difference in that.

We agree with Illich in his critique on processes of institutionalization. But, we would like to stick to the notion of school in the same way we want to stick to the notion of democracy. Of course, a lot of awful things happen in the name of democracy, but for us that is not a reason to leave out democracy. No, I think the concept is too precious to be left in the hands of those who abuse it.

For us, it is the same with the school.

[MASSCHELEIN] - It is very ambivalent with Illich. On the one hand, his critique of the school is in fact really this critique that, in order to learn, there is an institution that tells you that you need the institution to learn. He is criticizing this mechanism that makes you dependent on the institution and he wants a kind of independence from the institution.

But, on the other hand, if you go to other texts by Illich and not to the one you are referring to (Deschooling Society) - for example, texts on university, texts on writing -, then he comes very close to what we are trying to talk about: about what it means, for example, that you start to write, what it means that you start to work with texts and have that kind of attention to texts, and how he indicates the grammatizing that we are talking about. Then it

$\begin{array}{llllll}\text { (C) ETD-Educação Temática Digital } & \text { Campinas, SP } & \text { v.19 } & \text { n.4 } & \text { p. 705-719 } & \text { out./dez. } 2017\end{array}$ 
comes very close to what we are trying to say about school. But he seems to conflate the notion of school immediately with the institution.

You could say, to some extent, this is a kind of sociological perspective or political perspective, whereas we try to say: "We do not want that, but we want to try to see the school as a kind of pedagogic form, as a kind of pedagogical way of dealing with a new generation." So not primarily as an institution.

[INTERVIEWER] - At the end of In defence of the school we find the idea that it is necessary that the educator becomes a pedagogue. But the conception concerning what is a pedagogue is not very evident. Could you tell us what is a pedagogue in your conception?

[MASSCHELEIN] - (The slave) taking the child to the school, that is the meaning referring to what the 'pedagogue' was and did in ancient Greece. I think that it is really interesting today to maintain the notion of pedagogy in relation to this figure. I do not know if in Portuguese it is the same, but this notion of pedagogy is very often simply translated as "teaching." So pedagogy would be about teaching. It immediately relates to the teacher as well, and then there seems to be no difference between the pedagogue and the teacher. The difference is often simply forgotten. When one talks about pedagogy, it is about teaching, it is about the teacher.

However, one of the first images that we have of the pedagogue is precisely an image where there is a pedagogue and a teacher. They are not the same. Partly inspired by this image one could conceive of the pedagogue as the one who takes the child out of the house to the school and remains there in order to make sure that the school remains a school; that the love of the teacher for the child is not turning into a kind of pederast love, but remains a school love, remains the love for the new generation and does not become another kind of love. We could relate the pedagogue to the issue of the school.

We do not want to defend the teacher, we do not want to defend the student: we want to defend the school.

[SIMONS] - The pedagogue, in a way, is the one who takes care of the school. In that sense, you could even say that the pedagogue should not be the master of the teacher, but, he is a slave to the teachers. He is in service of the school. "In service" also meaning in care of the teachers.

But I think the pedagogue is not the teacher. Of course, the teacher is also a pedagogue, if he or she really is concerned with the school remaining a school.

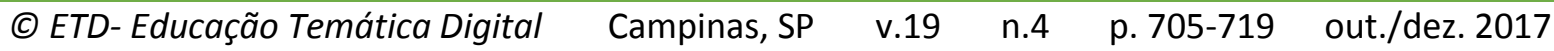


[MASSCHELEIN] - In practice, they can come together, but we could maybe say that the school teacher is really a school teacher if she is at once a pedagogue and a teacher.

[INTERVIEWER] - Do you have any questions that you would like to highlight or clarify?

[MASSCHELEIN] - It is something that we should also say, related to Geraldi's discussion again. It is a little bit strange to have this kind of reactions while we are very, very aware of all the critiques that have been formulated against the school: of normalization, of colonization, of institutionalization. All these things. That is our history, so to say; that is what we have been working on ourselves all the time.

So we do not want to deny it, we also do not want to forget it, but we try to develop, to take a different stance on the school. We think there is something really worthwhile in schools, which we tend to forget, what is made possible by school; those who are often in these critiques maybe too easily forget that they themselves went to school.

So that is not to defend the institution school and all the bad things that can, rightly, be related to school, but it is to find a way to precisely speak positively about the school, because there is something there.

[SIMONS] - There is a risk in those external perspectives repeating over and over again that school is reproducing social inequality. It puts teachers always in a very strange position. If it is about solutions, we are going to look at the teachers, so they should become socialization agents, or counter-socialization agents. That is something impossible, or at least something non-pedagogical, to ask from teachers.

We are not ignoring there is social reproduction; that is not the point of the book. The issue of equality perhaps can have a different meaning when starting from pedagogical practices and premises. You will not have to remind teachers or pedagogues that equality is an important issue. They are facing that every day. That is what they assume while teaching or making school; that is part of what they are, and how they try to relate to the coming generation as a teacher or pedagogue. But - and echoing Rancière - often we expect that teachers make our society more equal and use the coming generation for that. Isn't the school then becoming politics or social reform with other means, isn't school learning turned into counter-socialization? This is not about lowering our expectations towards schools and teachers, but having the right expectations.

[INTERVIEWER] - Thank you very much, Masschelein and Simons. 